\title{
Prediction and experimental confirmation of banana bract mosaic virus encoding miRNAs and their targets
}

\author{
Ramamoorthy Sankaranarayanan ${ }^{1}$ (D), Sankara Naynar Palani ${ }^{1}$ (D), Abhishek Kumar² (D), \\ Punitha Selvakumar A. S. ${ }^{1}$ (D) and Jebasingh Tennyson ${ }^{1 *}$ (iD
}

\begin{abstract}
Background: Potyviridae is the largest plant infecting family under the monophyletic group Riboviria, infects many of the food, fodder and ornamental crops. Due to the higher mutation and recombination rate, potyvirids are evolving rapidly, adapting to the environmental chaos and expanding their hosts. Virus control measures are need to be updated as the economic importance of potyvirids is massive. microRNAs (miRNAs) are well known for their functional importance in eukaryotes and many viruses. Regardless of its biogenesis, whether canonical or noncanonical, microRNA centric antivirus approaches attract the researchers to the hopeful future of nextgeneration broad-spectrum antiviral measures.

Methods: In this study, we predicted and screened banana bract mosaic virus (BBrMV) encoding miRNAs by computation approaches and their targets on banana transcriptome using plant small RNA target analysis server (psRNAtarget). The target gene functions were annotated by Blast2GO. The predicted BBrMV miRNAs were experimentally screened by stem-loop RT-PCR.

Results: The results showed that, among the predicted BBrMV miRNAs, miRNA2 is conserved throughout BBrMV isolates and has multiple virus-specific target transcripts. In addition, primary experimental validation for the predicted miRNAs revealed that miRNA2 exists in the BBrMV infected banana leaf samples.

Conclusions: The existence of BBrMV miRNA2 is confirmed by stem-loop RT-PCR followed by cloning and sequencing. The presence of miRNA of Potyviridae is rarely addressed and would definitely spread the hope to understand the virus infectious cycle. Our report would also help to better understand and manipulate potyviral infections.
\end{abstract}

Keywords: Banana bract mosaic virus, Virus miRNA, Potyviridae

\section{Background}

Potyviridae is the largest plant infecting family under the monophyletic group Riboviria, having ten genera and more than 200 species as per the ICTV classification 2018b release. More than 30\% of known plant viruses belong to this family. They are infecting a wide verity of economically important plants growing on diverse environmental conditions [1]. Potyvirids (members of Potyviridae) has single-stranded positive-sense RNA genome

\footnotetext{
*Correspondence: jebasinghs@gmail.com

${ }^{1}$ Department of Plant Sciences, School of Biological Sciences, Madurai

Kamaraj University, Madurai, Tamil Nadu, India

Full list of author information is available at the end of the article
}

which codes a polyprotein when entered into the cell. The polyprotein is cleaved into ten matured peptides in a time-dependent manner by three cognate proteases, P1 protease (P1), Helper component-protease (HcPro), and Nuclear inclusion a protease (NIa). The released mature peptides are functional units of virus infectious cycle. For a successful establishment of infection, viruses must alter the hosts' gene expression pattern.

Potyviral disease management often includes vector control, cross protections (infecting the plants with less virulent viruses to render immunity against severe strains) and develop transgenic resistant varieties. These routine control measures were less efficient and viruses

(c) The Author(s). 2020 Open Access This article is distributed under the terms of the Creative Commons Attribution 4.0 International License (http://creativecommons.org/licenses/by/4.0/), which permits unrestricted use, distribution, and reproduction in any medium, provided you give appropriate credit to the original author(s) and the source, provide a link to the Creative Commons license, and indicate if changes were made. The Creative Commons Public Domain Dedication waiver (http://creativecommons.org/publicdomain/zero/1.0/) applies to the data made available in this article, unless otherwise stated. 
are quickly evolving to evade or suppress these stratagems due to their high mutation and recombination rates [2].

Cumulative knowledge in the field of 'ribogenomics', sheds lights on the existence of dozens of non-coding RNA molecules and their functionality, especially miRNA [3]. miRNA is a small non-coding RNA of $\sim 24$ nt in length and are highly conserved in the plant kingdom [4]. miRNA plays an important role in posttranscriptional gene regulation by binding with its target mRNA, also known as 'RNA interference'. As a result, targeted mRNA may be cleaved [5] or the translation process is suppressed [6, 7]. A network of miRNAmRNA interactions determines most of the physiological and developmental processes of a cell [8-10].

It is well established that miRNAs produced by the plants help to suppress the viral genes expression [11]. In turn, viruses are evolved to utilize host miRNAs for their tropism, polyprotein processing etc. [12, 13]. It has been well documented that potyvirids encode RNA silencing suppressors (P1 and HcPro) which are used to counter the host RNA interference mechanisms by hindering the miRNA biogenesis pathways of host and thus potyvirids alter the hosts' gene expression pattern [14]. On the other hand, extensive studies on the virus infectious cycle unveiled that most of the viruses could code miRNAs [15]. However, miRNAs of potyviral origin are rarely reported and not well understood. Viswanathan et al. (2014) reported sugarcane streak mosaic virus (SCSMV) coding miRNA and their targets in sugarcane [16]. To our best knowledge, this is the only available report that claims miRNA of Potyviridae origin. Identifying potyvirids encoding miRNAs and their roles during infection opens a bunch of opportunities to manipulate the viral infectious cycle. Banana is one of the most valuable staple foods and well known for its nutrition and several bioactive compounds [17]. Banana bract mosaic virus (belonging to Potyviridae family), Banana bunchy top virus (Nanoviridae), Banana streak virus (Caulimoviridae), cucumber mosaic virus (Bromoviridae) etc. are the well-known virus pathogens. Banana bract mosaic virus (BBrMV) is distributed in Asia and the south pacific, causes the yield loss up to $70 \%[18,19]$. BBrMV isolates infecting flowering ginger and small cardamom raising a serious concern about BBrMV disease managements [20, 21]. In this study, we predicted and screened BBrMV encoding miRNA and their functions to understand 'miRNA mediation in potyvirus infection'.

\section{Results}

Prediction and annotation of BBrMV encoding miRNAs

There were totally seven miRNAs predicted from BBrMV genome. The predicted primary and mature miRNA sequences and their position on BBrMV genome have been listed in Table 1 . The stem-loop structure for the primary miRNA transcripts was validated by RNAFold [22] and given in Fig. 1. The predicted primary miRNA sequence was subjected to the screening of miRNA specific signatures as per the Meyers' criteria [23]. The primary miRNA sequence length, anywhere between 60 and $150 \mathrm{nt}$ was preferred and others been rejected. The mismatch between the mature miRNA and its miRNA* in the stem region should not be more than 5. The AU content must be in the range between 30 and $70 \%$. Minimum free energy (MFE) and minimum free energy index (MFEI) for the predicted secondary structures also used to scrutinize the candidate selection. MFE denotes the negative folding free energy $(\Delta G)$ which needs to be in the negative value. MFEI was calculated to filter out the false positives, by using the following formula, MFEI $=[($ MFE/length of the pre-miRNA sequence $) \times 100] /(\mathrm{G}+\mathrm{C})$ percentage. The MFE (kcal/ $\mathrm{mol})$, MFEI ( $\mathrm{kcal} / \mathrm{mol})$, number of mismatches between miRNA and miRNA* and AU content for the predicted miRNA are listed in Table 2. Lower MFE values and MFEI less than $-0.5 \mathrm{kcal}$ further ensures the likely hood of predicted vmiRNA [23]. Among the predicted BBrMV miRNAs, five were selected for experimental screening as BBrMV miRNA5, BBrMV miRNA6 has more than 5 mismatches (Table 2).

\section{Experimental validation of BBrMV miRNAs}

The RNA was extracted from BBrMV infected and uninfected banana leaf samples and the carryover genomic DNA contamination were removed by DNaseI treatment (Fig. 2a). The DNase I treated total RNA was used for further procedures. cDNA from BBrMV infected and control banana samples were prepared with oligo dT primer and the template quality was tested with monocot actin gene amplification. Both samples successfully amplified the intron-less monocot actin gene at $\sim 650 \mathrm{bp}$ (Fig. 2b).

The cDNAs synthesized by stem-loop RT-PCR was further subjected to perform endpoint PCR and the product was confirmed by $4 \%$ agarose gel electrophoresis (Fig. 2c). The expected ( $70 \mathrm{bp})$ amplicon was observed for BBrMV miRNA2 whereas no detectable amplification for other BBrMV miRNAs and uninfected plant cDNA (Fig. 2d). Further, the amplified product (BBrMV miRNA2) was cloned in pGEM-T easy vector. The clone pGEM-T vmiRNA was confirmed by sequencing with M13.F primer (Additional file 1: Figure S1).

\section{Target predictions}

As the complementarity between miRNA and mRNA is near perfect, target transcripts (predicted by psRNATarget server) having the maximum expectation value less than or equal to 3 were only considered. The 
Table 1 Annotation of the predicted vmiRNA sequences

\begin{tabular}{|c|c|c|c|}
\hline miRNA ID and Sequence ${ }^{a}$ & Orientation & Positions $^{b}$ & Locus \\
\hline BBrMV miRNA 1 & Forward & 1807 to 1888 & HcPro \\
\hline Sequence & \multicolumn{3}{|c|}{$\begin{array}{l}\text { GGUAUCAGUCGUAUGAGUUACGAGUAUCUCCAAAUUGUACUAGGAAACUAGCAAUUGGAAGAUUGUUGGUCUCAA } \\
\text { CGAAUAU }\end{array}$} \\
\hline BBrMV miRNA 2 & Forward & 3672 to 3763 & $6 \mathrm{~K} 1-\mathrm{Cl}$ \\
\hline Sequence & \multicolumn{3}{|c|}{$\begin{array}{l}\text { GUGGGGUUUCAGAAUUUAGAUGAGAUACAAGAUAUUGAAGCAGAGAAGAAGACAACAAUUGAUUUCAUCUUAGCUGAUGA } \\
\text { UACACCACTCGC }\end{array}$} \\
\hline BBrMV miRNA 3 & Forward & 204 to 285 & P1 protein \\
\hline Sequence & \multicolumn{3}{|c|}{$\begin{array}{l}\text { UCGCCAACGAGUGUUAAGAUGACAGUCGCACCACAAUGCAUGGCGGCACUAGAGGUGGAAUGUGAUACAA } \\
\text { CACUUAAGGCGG }\end{array}$} \\
\hline BBrMV miRNA 4 & Forward & 4192 to 4264 & $\mathrm{Cl}$ \\
\hline Sequence & \multicolumn{3}{|c|}{ UCAUAAUCCUUGAUGAAUGUCAUGUUAUGGAUGCUUCAGCAAUGGCGUUCUAUUGUCUACUCAAGGAGUAUGC } \\
\hline BBrMV miRNA 5 & Forward & 6710 to 6808 & Nla \\
\hline Sequence & \multicolumn{3}{|c|}{ 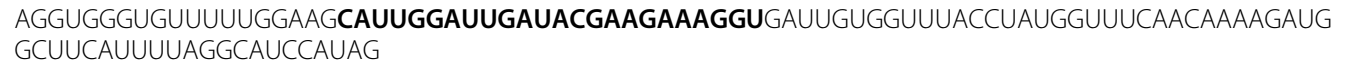 } \\
\hline BBrMV miRNA 6 & Reverse & 294-194 & P1 \\
\hline Sequence & \multicolumn{3}{|c|}{$\begin{array}{l}\text { CUGGCGUCGCCGCCUUAAGUGUUGUAUCACAUUCCACCUCUAGUGCCGCCAUGCAUUGUGGUGCGACUGUCAUC } \\
\text { UUAACACUCGUUGGCGAUGCUGGCUCU }\end{array}$} \\
\hline BBrMV miRNA 7 & Reverse & 5225 to 5318 & $\mathrm{Cl}$ \\
\hline Sequence & \multicolumn{3}{|c|}{$\begin{array}{l}\text { AAGUGUGCGGGGAAUUGCAAACGAAUCGCAACUGAGAGUGUAUGCAAUUGAGCAUGCACUCGCUGUUGUGAGU } \\
\text { CGUCCAAACCCAGCAUCAGUU }\end{array}$} \\
\hline
\end{tabular}

${ }^{a}$ The mature miRNA sequence is mentioned in bold letters

*Position of pri miRNA in the virus genome

expectation value is the penalty for the mismatches between mature miRNA and the target sequence. The predicted target sequences were collected and subjected to gene ontology studies. BBrMV miRNA ids, target accession numbers and their corresponding functions are listed in Additional file 1: Table S1. Many of the BBrMV miRNA2 target transcripts show specificity to virus infectious cycle.

For example, Guanyl-nucleotide exchange factor (GEF) (GO:0005086) was proved as an essential factor for hepatitis E virus replication [24]. In plant virus as well, the involvement of GEF in the translation initiation process was proved via mutation studies on turnip mosaic virus (TuMV) [25]. Many other targets are involved in the protein kinase pathway, magnesium ion transporter system etc. (Additional file 1: Figure S2).

\section{Discussion}

Virus miRNA

Virus miRNAs were first identified by Pfeffer et al., (2004). Subsequent studies unveiled many viruses that have been shown to code their own miRNA [26]. Currently, miRBase contains miRNA records for more than 30 different viruses. Studies also revealed that viruses could alter the host miRNA biogenesis, accumulation, turnover, and functions [27-29]. Surprisingly, sequence conservation is also reported in miRNAs sequences between related viruses or between viral
miRNAs and cellular miRNAs [30]. The conservation nature of the BBrMV miRNAs 1, 2, 3, 4 and 7 were studied. Interestingly, BBrMV miRNA2 shows 100\% conservation among the available four BBrMV isolates including ginger infecting $\mathrm{BBrMV}$ isolate whereas in other miRNAs, few nucleotides are not conserved among the BBrMV isolates (Additional file 1: Table S2; Additional file 1: Figure S3). This might be the reason behind the amplification of BBrMV miRNA2. Further, miRNA expression may also get affected by stages of virus infections and types of tissues. More studies on biogenesis of potyvirid miRNAs and their expression dynamics in respect to stages of infectious cycle should be performed to verify the feasibility.

\section{Virus miRNA biogenesis}

Viruses do not have its own translation machinery hence the host is necessary for translation of the viral genome. This is true for the miRNA biogenesis as well. However, the exceptionality found in virus should also be considered in all aspects of their life processes. DNA viruses could enter into the nucleus of the host and their genome is transcribed into the pri-miRNA transcript. Pri-miRNA then folds and follows the host miRNA biogenesis steps to produce virus miRNA [26]. It is also found that in some DNA viruses, the one or many intermediate steps in the miRNA biogenesis process are skipped [31]. 


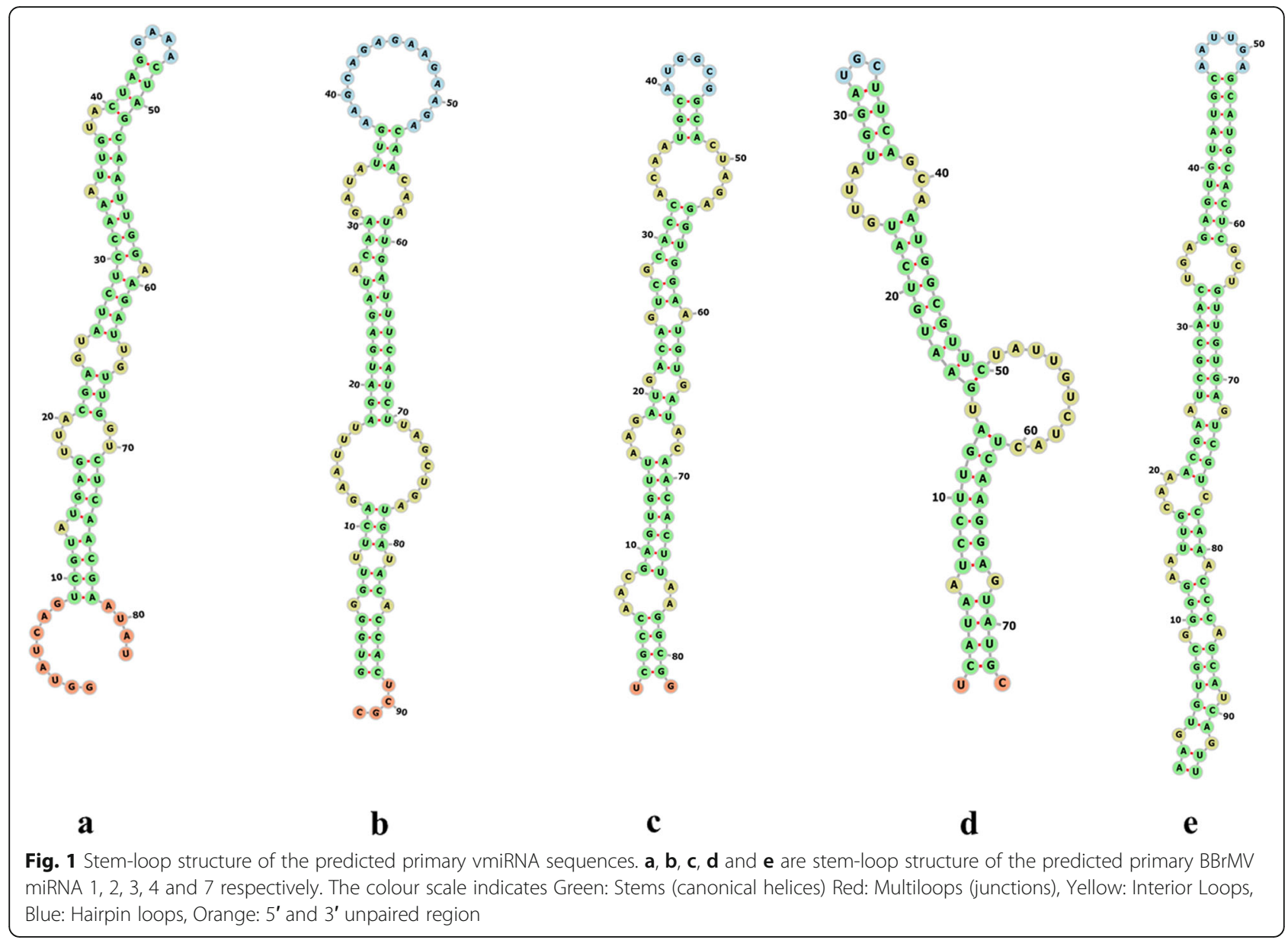

Subsequent studies in the DNA viruses unravelled the existence of many non-canonical pathways [32-34].

In plant DNA viruses, analysis of 18 to 24 nt RNAs derived from the virus genome confirmed that these RNAs were generated by Dicer-like proteins, methylated at the 3' end by HUA ENHANCER1 (HEN1) [35]. Another similar study also unveiled the involvement of four Dicer-like proteins in the virus miRNA biogenesis [36].
These studies showed the biogenesis of DNA virusencoded miRNAs in plants.

It was believed that the cytoplasmic RNA viruses unable to code miRNAs, as their entire infectious cycle sited at the cytoplasm. However, studies confirmed many of the plant and animal cytoplasmic RNA viruses also able to code miRNAs [37-39]. Studies revealed that cytoplasmic processing of pri-miRNAs is independent of

Table 2 Characterization of the predicted vmiRNAs

\begin{tabular}{|c|c|c|c|c|}
\hline miRNA ID & MFE (kcal/mol) & $\begin{array}{l}\text { MFEl } \\
\text { (kcal/mol) }\end{array}$ & number of mismatches & AU content (\%) \\
\hline aBrMV miRNA 1 & -21.50 & -0.67 & 5 & 61 \\
\hline 'BBrMV miRNA2 & -19.60 & -0.56 & 3 & 62 \\
\hline aBBrMV miRNA 3 & -26.10 & -0.62 & 5 & 49 \\
\hline aBBrMV miRNA 4 & -20.20 & -0.69 & 2 & 60 \\
\hline BBrMV miRNA 5 & -26.10 & -0.67 & 10 & 61 \\
\hline BBrMV miRNA 6 & -38.80 & -0.71 & 6 & 46 \\
\hline aBBrMV miRNA 7 & -41.40 & -0.89 & 4 & 51 \\
\hline
\end{tabular}

${ }^{a}$ miRNA candidates used for experimental screening were satisfied with Meyers' criteria 

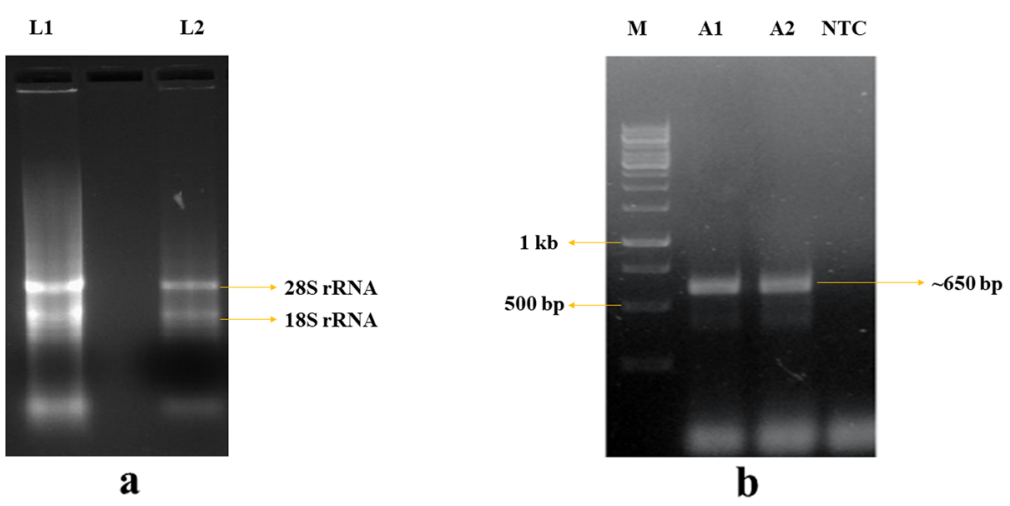

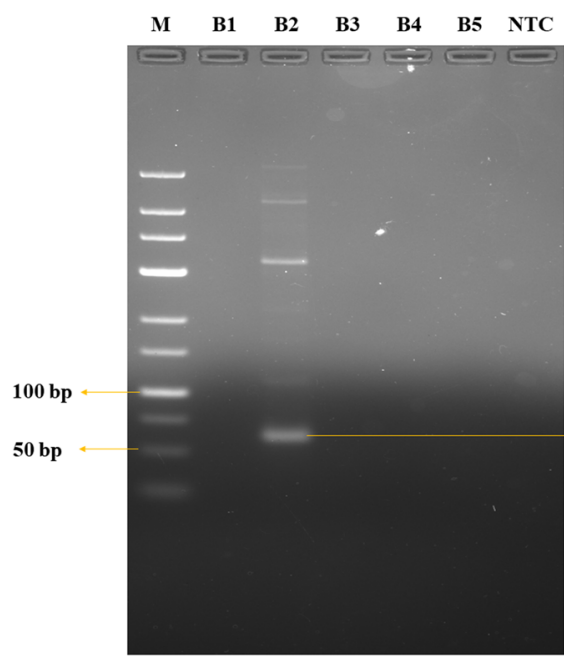

c

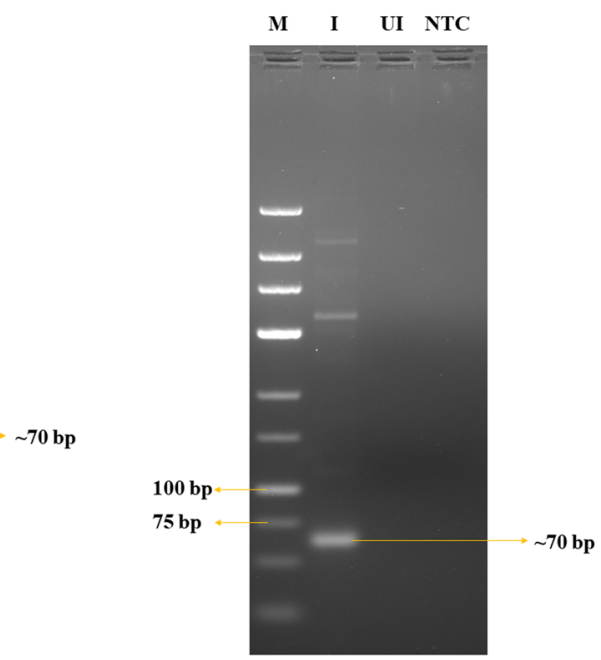

d

Fig. 2 Experimental validation. a. RNA isolation from the banana plant. Lane 1- Before DNAse treatment. Lane 2- After DNAse treatment. b Amplification of monocot actin gene. Analysed reaction products using agarose gel electrophoresis (1\%) in 1× TAE. M - $1 \mathrm{~Kb}$ ladder. A1 Monocot actin amplification from uninfected banana. A2 - Monocot actin amplification from BBrMV infected banana. NTC - Non-template control. c. Amplification of predicted vmiRNAs from BBrMV infected banana leaf sample. Analysed reaction products using agarose gel electrophoresis (4\%) in 1× TAE. M - Low range DNA ladder. B1 - BBrMV miRNA 1. B2 - BBrMV miRNA 2. B3 - BBrMV miRNA 3. B4 - BBrMV miRNA 4. B5 - BBrMV miRNA 7. NTC - Non-template control. d. Amplification of BBrMV miRNA2 from BBrMV infected and uninfected banana samples. Analysed reaction products using agarose gel electrophoresis (4\%) in 1× TAE. M - Low range marker. I - BBrMV infected banana plant showing the amplification of BBrMV miRNA2. Con - Uninfected banana plant showing the absence of BBrMV miRNA2 amplification. NTC - Non-template control

a hairpin structure, transcript positioning, independent of cell division and even nuclear access [39-41].

Surprisingly, hibiscus chlorotic ringspot virus (HCRV), a species of Tombusviridae having positive ssRNA genome has shown the presence of its genome in the host nucleus. The authors hypothesised that nuclear localization of the HCRV genome is for the miRNA biogenesis [42]. The presence of miRNA in the Potyviridae species was rarely addressed. Viswanathan et al. (2014) predicted the sugarcane streak mosaic virus (SCSMV) coded miRNA and experimentally validated by stem-loop RT-PCR and reverse RNA blot hybridization techniques. Heretofore, to our best knowledge, this is the only report of miRNA of potyviral origin. At this juncture, our findings would lead to the consequence understanding of miRNA mediation in potyvirid infections. RNAi has been used as a robust defence mechanism by plants against viral pathogens [43, 44]. RNAi centric methods are more auspicious for efficient disease management. Understanding of miRNA mediation in potyviral infection is necessary to achieve successful RNAi based viral resistance.

\section{Conclusion}

In summary, we predicted BBrMV miRNAs and their targets. Experimental screening of BBrMV miRNAs showed the amplification for BBrMV miRNA2. BBrMV miRNA2 is satisfying its existence by considering the following points. 
- Mature miRNA sequence is $100 \%$ conserved among the BBrMV isolates (even in the ginger infecting BBrMV isolate as well).

- Having amplified in stem-loop RT-PCR, which is known as the most accurate method for miRNA conformation [45].

- Amplification was observed only in the BBrMV infected banana samples but not in the uninfected/ healthy samples.

- The BLAST search of BBrMV miRNA2 pri miRNA transcript, against the banana genome, did not return any hits.

- BBrMV miRNA2 have many targets related to virusspecific functions.

These compelling shreds of evidence provide the hope towards the possibilities of virus miRNA (vmiRNA) coded by Potyviridae family of viruses.

\section{Materials and methods \\ Prediction of potential miRNAs of BBrMV}

BBrMV complete genome sequence (NC_009745.1) was retrieved from the NCBI database. The genome sequence was then subjected to VMir, a program to predict potential miRNA precursors in viral genomes or other nucleotide sequences of approximately $2 \mathrm{Mb}$ [46]. The predicted miRNA precursors obtained from VMir were then classified into real and pseudo precursors miRNA sequences using MiPred tool, which utilizes a hybrid algorithm in order to differentiate the real precursors miRNAs from pseudo precursors miRNAs with similar stem-loops [47]. The real precursor miRNA sequences obtained from MiPred were then used to predict mature miRNA sequences by using miRPara, SVMbased computational tool for identifying most potent mature miRNA coding regions from genomic sequences [48]. The schematic illustration of miRNA prediction is shown in Additional file 1: Figure S4.

\section{Experimental validation Sample collection}

Healthy and banana bract mosaic virus (BBrMV) infected banana plant leaves were collected from the National Research Centre for Banana (NRCB), Somarasempettai - Thogaimalai Road, Podavur, Trichirappalli, Tamil Nadu. The infected plant samples were washed in distilled water twice and rinsed with $0.1 \%$ diethyl pyrocarbonate (DEPC) solution. Washed leaves were cut into pieces and stored in $-80{ }^{\circ} \mathrm{C}$ freezer.

\section{Total RNA isolation}

Total RNA was isolated from frozen healthy and BBrMV infected banana leaf samples by the method as described in Palani et al. (2019) [49]. DNase treatment was done by the standard protocol as given. The DNase treated RNA was used for further procedures. The freshly prepared healthy and infected cDNAs were used to amplify the monocot actin coding region to confirm that no genomic DNA carryover in the template.

\section{Confirmation of RNA quality by amplifying monocot actin gene}

1 microgram of DNase treated total RNA of healthy and BBrMV infected samples were taken for cDNA synthesis. $0.5 \mu \mathrm{g}$ of oligo dT primer $(0.5 \mu \mathrm{g} / \mu \mathrm{l})$ was added and made up reaction volume to $10 \mu \mathrm{l}$. The mixture was heated at $70{ }^{\circ} \mathrm{C}$ for $10 \mathrm{~min}$ and quick-chilled on ice. After this primer annealing step, $5 \mathrm{X}$ FirstStrand Reaction Buffer $(4 \mu \mathrm{l}), 0.1 \mathrm{M}$ DTT $(2 \mu \mathrm{l}), 10 \mathrm{mM}$ dNTP mix $(1 \mu \mathrm{l})$ were added and incubated at $45^{\circ} \mathrm{C}$ for $2 \mathrm{~min}$ to equilibrate the temperature. Then $1 \mu \mathrm{l}$ of Superscript III RT $(200 \mathrm{U} / \mu \mathrm{l})$ was added and incubated at $45^{\circ} \mathrm{C}$ for $1 \mathrm{~h}$.

$1 \mu \mathrm{l}$ of diluted (1:10 ratio) cDNA was added to the PCR mixture containing $1 \mathrm{U}$ of Taq polymerase, $200 \mu \mathrm{M}$ dNTPs, $1.5 \mathrm{mM}$ of $\mathrm{MgCl}_{2}$, 1X Taq buffer with forward (5'-GAGAARATGACMCARATYATG-3') and reverse (5'-TCMACRTCRCACTTCATGAT-3' primers. Initial denaturation was performed at $94^{\circ} \mathrm{C}$ for $2 \mathrm{~min}$ and the final extension was performed at $72{ }^{\circ} \mathrm{C}$ for $8 \mathrm{~min}$. The annealing temperature, annealing time and extension time were varied according to the melting temperatures of the primers and expected amplicon size. The PCR products were analyzed on an agarose gel.

\section{Designing of primers to amplify the predicted BBrMV miRNA}

Stem-loop RT-PCR primers for the predicted BBrMV miRNA were designed according to Varkonyi-Gasic and Hellens, (2011) method [45]. The primers are listed in (Additional file 1: Table S3).

\section{Stem-loop RT-PCR}

The schematic illustration of stem-loop RT-PCR is shown in (Additional file 1: Figure S5.

\section{Preparation of stem-loop primer master mix}

In order to screen the predicted BBrMV encoding miRNAs from host transcripts, the master mix was prepared by adding the following components:

$11.15 \mu \mathrm{l}$ of water, $0.5 \mu \mathrm{l}$ of $10 \mathrm{mM}$ dNTPs and 1 microgram of RNA $(1 \mu \mathrm{l})$ was added in an eppendorff tube and the tube was incubated at $65^{\circ} \mathrm{C}$ for $5 \mathrm{~min}$ and then kept on ice for $2 \mathrm{~min}$. To this, $4 \mu \mathrm{l}$ of $5 \mathrm{X}$ first strand buffer, $2 \mu \mathrm{l}$ of $0.1 \mathrm{M}$ DTT. $0.1 \mu \mathrm{l}$ of RNAseOUT (40 u/ $\mu \mathrm{l})$ and $0.25 \mu \mathrm{l}$ of Superscript III $(200 \mathrm{U} / \mu \mathrm{l})$ were added to give the final volume of $19 \mu \mathrm{l}$. Then, the denatured stem-loop primer $(1 \mu \mathrm{l})$ was added. The PCR conditions 
were $30 \mathrm{~min}$ at $16^{\circ} \mathrm{C}$ followed by pulsed RT (60 cycles) at $30^{\circ} \mathrm{C}$ for $30 \mathrm{~s}, 42^{\circ} \mathrm{C}$ for $30 \mathrm{~s}$, and $50^{\circ} \mathrm{C}$ for $1 \mathrm{~s}$. Finally, the reaction was incubated at $85^{\circ} \mathrm{C}$ for $5 \mathrm{~min}$ to inactivate the reverse transcriptase enzyme.

\section{End-point PCR}

The presence of miRNA was confirmed by amplification of the reverse transcribed product (obtained with miRNA specific stem-loop primers) with a universal reverse primer and the miRNA specific forward primer (Additional file 1: Table S3).

The PCR components were $15.4 \mu \mathrm{l}$ of water, $2 \mu \mathrm{l}$ of 10 $\mathrm{X}$ buffer, $0.4 \mu \mathrm{l}$ of $10 \mathrm{mM}$ dNTPs, $0.4 \mu \mathrm{l}$ of miRNA specific forward primer, $0.4 \mu \mathrm{l}$ of universal reverse primer, $0.4 \mu \mathrm{l}$ of Taq DNA polymerase (Sigma) and $1 \mu \mathrm{l}$ of cDNA in a PCR tube. The following conditions were used for the amplification: $94{ }^{\circ} \mathrm{C}$ for $2 \mathrm{~min}$, followed by 45 cycles of $94{ }^{\circ} \mathrm{C}$ for $15 \mathrm{~s}$ and $60^{\circ} \mathrm{C}$ for $1 \mathrm{~min}$. The amplified products were analysed by electrophoresis on a $4 \%$ agarose gel in $1 \mathrm{X}$ TAE.

\section{Cloning and sequencing of amplified miRNA}

The amplified product of endpoint PCR was eluted and cloned in pGEM-T easy vector and screened by bluewhite screening. A positive clone of pGEM-T vmiRNA was sequenced by M13.F primer.

\section{Target prediction}

Plant Small RNA Target Analysis Server (psRNAtarget) hosted at http://plantgrn.noble.org/psRNATarget/home was used to predict the BBrMV miRNA targets on banana transcripts using default parameters [50]. The target sequences were downloaded and annotated by using Blast2GO tool to decipher their function.

\section{Supplementary information}

Supplementary information accompanies this paper at https://doi.org/10. 1186/s41544-019-0044-7.

Additional file 1: Figure S1. BBrMV miRNA2 sequencing chromatogram image. Table S1. Predicted BBrMV miRNA targets and their functions. Figure S2. Gene Ontology (GO) analysis of the BBrMV miRNA2 target genes using Blast2GO. Figure S3. The multiple sequence alignment of the predicted BBrMV miRNA sequences among Philippines, Trichy, Wayanad and Ginger infecting BBrMV isolates. Table S2. Number of mismatches at mature miRNA sequences between the isolates of BBrMV. Figure S4. Stepwise virus miRNA prediction scheme. Figure S5. Schematic representation of stem-loop RT-PCR. Table S3. Primers to screen BBrMV miRNA sequences.

\section{Abbreviations}

BBrMV: Banana bract mosaic virus; CMV: Cucumber mosaic virus; HCPro: Helper component-protease; HCRV: Hibiscus chlorotic ringspot virus; HEN1: Hua enhancer1; ICTV: International Committee on Taxonomy of Viruses; MFE: Minimum free energy; MFEl: Minimum free energy index; Nla: Nuclear inclusion a protease; P1: P1 protease; RNAi: RNA interference; SCSMV: Sugarcane streak mosaic virus; TBSV: Tomato bushy stunt virus; TuMV: Turnip mosaic virus

\section{Acknowledgements}

We thank Dr. R. Selvarajan, and Dr. S. Backiyarani, National Research Centre for Banana (NRCB), Somarasempettai - Thogaimalai Road, Podavur, Trichirappalli, Tamil Nadu, India, for providing BBrMV infected banana plant samples.

\section{Authors' contributions}

Jebasingh Tennyson conceived the idea. Ramamoorthy Sankaranarayanan and Sankara Naynar Palani planned and performed the experiments. Abhishek Kumar predicted BBrMV miRNAs. Punitha Selvakumar collected the target transcripts and helped to perform GO studies. All authors read and approved the final manuscript.

\section{Funding}

This work was supported by the Council of Scientific and Industrial Research (CSIR), Government of India (Scheme No. 38(1321)/12/EMR-II).

\section{Availability of data and materials}

All data generated or analysed during this study are included in this published article.

\section{Ethics approval and consent to participate}

This article does not contain any studies with human participants performed by any of the authors.

\section{Consent for publication}

Not applicable.

\section{Competing interests}

All authors declare that they have no competing interests.

\section{Author details}

${ }^{1}$ Department of Plant Sciences, School of Biological Sciences, Madurai Kamaraj University, Madurai, Tamil Nadu, India. ${ }^{2}$ Department of Biochemistry, Indian Institute of Science, Bangalore, Karnataka, India.

Received: 4 July 2019 Accepted: 5 November 2019

Published online: 03 February 2020

\section{References}

1. Sharma P, Sahu AK, Verma RK, Mishra R, Choudhary DK, Gaur RK. Current status of potyvirus in India. Arch Phytopathol Plant Protect. 2014:47(8):906-18

2. Sanjuan R. From molecular genetics to phylodynamics: evolutionary relevance of mutation rates across viruses. PLoS Pathog. 2012;8(5):e1002685.

3. Wu J, Xiao J, Zhang Z, Wang X, Hu S, Yu J. Ribogenomics: the science and knowledge of RNA. Genom Proteomics Bioinform. 2014;12(2):57-63.

4. Axtell MJ, Meyers BC. Revisiting criteria for plant microRNA annotation in the era of big data. Plant Cell. 2018;30(2):272-84

5. Llave C, Xie Z, Kasschau KD, Carrington JC. Cleavage of scarecrow-like mRNA targets directed by a class of Arabidopsis miRNA. Science. 2002; 297(5589):2053-6.

6. Aukerman MJ, Sakai H. Regulation of flowering time and floral organ identity by a microRNA and its APETALA2-like target genes. Plant Cell. 2003; 15(11):2730-41.

7. Chen X. A microRNA as a translational repressor of APETALA2 in Arabidopsis flower development. Science. 2004;303(5666):2022-5

8. Sabzehzari M, Naghavi MR. Phyto-miRNA: A molecule with beneficial abilities for plant biotechnology. Gene. 2018;2(683):28-34.

9. Nonomura KI. Small RNA pathways responsible for non-cell-autonomous regulation of plant reproduction. Plant Reprod. 2018;31(1):21-9.

10. Zhou H, Hussain SS, Hackenberg M, Bazanova N, Eini O, Li J, Gustafson P, Shi B. Identification and characterisation of a previously unknown drought tolerance-associated micro RNA in barley. Plant J. 2018;95(1):138-49.

11. Jiang S, Jiang L, Yang J, Peng J, Lu Y, Zheng H, Lin L, Chen J, Yan F. Overexpression of Oryza sativa Xrn4 confers plant resistance to virus infection. Gene. 2018;639:44-51.

12. Sarnow $P$, Sagan SM. Unraveling the mysterious interactions between hepatitis C virus RNA and liver-specific microRNA-122. Ann Rev Virol. 2016;3: 309-32. 
13. Guo YE, Steitz JA. Virus meets host microRNA: the destroyer, the booster, the hijacker. Mol Cell Biol. 2014;34(20):3780-7.

14. Qu F, Morris TJ. Suppressors of RNA silencing encoded by plant viruses and their role in viral infections. FEBS Lett. 2005:579(26):5958-64.

15. Cullen BR. Viruses and microRNAs. Nat Genet. 2006;38(6s):S25.

16. Viswanathan C, Anburaj J, Prabu G. Identification and validation of sugarcane streak mosaic virus-encoded microRNAs and their targets in sugarcane. Plant Cell Rep. 2014;33(2):265-76.

17. Singh B, Singh JP, Kaur A, Singh N. Bioactive compounds in banana and their associated health benefits-a review. Food Chem. 2016;206:1-11.

18. Ploetz RC, Kema GH, Ma LJ. Impact of diseases on export and smallholder production of banana. Annu Rev Phytopathol. 2015;53:269-88.

19. Kumar PL, Selvarajan R, Iskra-Caruana ML, Chabannes M, Hanna R. Biology, etiology, and control of virus diseases of banana and plantain. In Advances in virus research. 2015:91:229-69. Academic Press.

20. Zhang J, Borth WB, Lin B, Dey KK, Melzer MJ, Shen H, et al. Deep sequencing of banana bract mosaic virus from flowering ginger (Alpinia purpurata) and development of an immunocapture RT-LAMP detection assay. Arch Virol. 2016;161(7):1783-95.

21. Bhat Al, Pamitha NS, Gopika A, Biju CN. Complete genome sequencing of banana bract mosaic virus isolate infecting cardamom revealed its closeness to banana infecting isolate from India. VirusDisease. 2018;29(2):212-5.

22. Lorenz R, Bernhart SH, Zu Siederdissen CH, Tafer H, Flamm C, Stadler PF, Hofacker IL. ViennaRNA Package 2.0. Algorithms Mol Biol. 2011;6(1):26.

23. Meyers BC, Axtell MJ, Bartel B, Bartel DP, Baulcombe D, Bowman JL, Cao X, Carrington JC, Chen X, Green PJ, Griffiths-Jones S. Criteria for annotation of plant MicroRNAs. Plant Cell. 2008;20(12):3186-90.

24. Farhat R, Ankavay M, Lebsir N, Gouttenoire J, Jackson CL, Wychowski C, Moradpour D, Dubuisson J, Rouille Y, Cocquerel L. Identification of GBF1 as a cellular factor required for hepatitis E virus RNA replication. Cell Microbiol. 2018;20(1):e12804

25. Shopan J, Mou H, Zhang L, Zhang C, Ma W, Walsh JA, Hu Z, Yang J, Zhang M. Eukaryotic translation initiation factor 2B-beta (elF 2Bß), a new class of plant virus resistance gene. Plant J. 2017;90(5):929-40.

26. Pfeffer S, Zavolan M, Grasser FA, Chien M, Russo JJ, Ju J, John B, Enright AJ, Marks D, Sander C, Tuschl T. Identification of virus-encoded microRNAs. Science. 2004;304(5671):734-6.

27. Trobaugh DW, Gardner CL, Sun C, Haddow AD, Wang E, Chapnik E, Mildner A, Weaver SC, Ryman KD, Klimstra WB. RNA viruses can hijack vertebrate microRNAs to suppress innate immunity. Nature. 2014;506(7487):245.

28. Zhang C, Ding Z, Wu K, Yang L, Li Y, Yang Z, Shi S, Liu X, Zhao S, Yang Z, Wang $Y$. Suppression of jasmonic acid-mediated defense by viral-inducible MicroRNA319 facilitates virus infection in rice. Mol Plant. 2016;9(9):1302-14.

29. Gazzani S, Li M, Maistri S, Scarponi E, Graziola M, Barbaro E, Wunder J, Furini A, Saedler H, Varotto C. Evolution of MIR168 paralogs in Brassicaceae. BMC Evol Biol. 2009;9(1):62.

30. Walz N, Christalla T, Tessmer U, Grundhoff A. A global analysis of evolutionary conservation among known and predicted gammaherpesvirus microRNAs. J Virol. 2010;84(2):716-28.

31. Tycowski KT, Guo YE, Lee N, Moss WN, Vallery TK, Xie M, Steitz JA. Viral noncoding RNAs: more surprises. Genes Dev. 2015;29(6):567-84.

32. Cazalla D, Xie M, Steitz JA. A primate herpesvirus uses the integrator complex to generate viral microRNAs. Mol Cell. 2011;43(6):982-92.

33. Bogerd HP, Karnowski HW, Cai X, Shin J, Pohlers M, Cullen BR. A mammalian herpesvirus uses noncanonical expression and processing mechanisms to generate viral MicroRNAs. Mol Cell. 2010;37(1):135-42.

34. Diebel KW, Smith AL, van Dyk LF. Mature and functional viral miRNAs transcribed from novel RNA polymerase III promoters. Rna. 2010;16(1):170-85.

35. Akbergenov R, Si-Ammour A, Blevins T, Amin I, Kutter C, Vanderschuren H, Zhang P, Gruissem W, Meins F Jr, Hohn T, Pooggin MM. Molecular characterization of geminivirus-derived small RNAs in different plant species. Nucleic Acids Res. 2006;34(2):462-71.

36. Blevins T, Rajeswaran R, Shivaprasad PV, Beknazariants D, Si-Ammour A, Park HS, Vazquez F, Robertson D, Meins F Jr, Hohn T, Pooggin MM. Four plant dicers mediate viral small RNA biogenesis and DNA virus induced silencing. Nucleic Acids Res. 2006:34(21):6233-46.

37. Swaminathan G, Martin-Garcia J, Navas-Martin S. RNA viruses and microRNAs: challenging discoveries for the 21st century. Physiol Genomics. 2013;45(22):1035-48.

38. Hussain M, Torres S, Schnettler E, Funk A, Grundhoff A, Pijlman GP, Khromykh AA, Asgari S. West Nile virus encodes a microRNA-like small RNA in the $3^{\prime}$ untranslated region which up-regulates GATA4 mRNA and facilitates virus replication in mosquito cells. Nucleic Acids Res. 2011:40(5): 2210-23.

39. Shapiro JS, Langlois RA, Pham AM. Evidence for a cytoplasmic microprocessor of pri-miRNAs. Rna. 2012;18(7):1338-46.

40. Rouha $\mathrm{H}$, Thurner $\mathrm{C}$, Mandl CW. Functional microRNA generated from a cytoplasmic RNA virus. Nucleic Acids Res. 2010;38(22):8328-37.

41. Langlois RA, Shapiro JS, Pham AM. In vivo delivery of cytoplasmic RNA virus-derived miRNAs. Mol Ther. 2012;20(2):367-75.

42. Gao R, Liu P, Wong SM. Identification of a plant viral RNA genome in the nucleus. PLoS One. 2012:7(11):e48736.

43. Calil IP, Fontes EP. Plant immunity against viruses: antiviral immune receptors in focus. Ann Bot. 2016;119(5):711-23.

44. Yang Z, Li Y. Dissection of RNAi-based antiviral immunity in plants. Curr Opin Virol. 2018:32:88-99.

45. Varkonyi-Gasic E, Hellens RP. Quantitative stem-loop RT-PCR for detection of microRNAs. In RNAi and Plant Gene Function Analysis. 2011;145-57. Humana Press.

46. Grundhoff A, Sullivan CS. Virus-encoded microRNAs. Virology. 2011;411(2): $325-43$

47. Jiang $P$, Wu H, Wang W, Ma W, Sun X, Lu Z. MiPred: classification of real and pseudo microRNA precursors using random forest prediction model with combined features. Nucl Acids Res. 2007;35(suppl_2):W339-44.

48. Wu Y, Wei B, Liu H, Li T, Rayner S. MiRPara: a SVM-based software tool for prediction of most probable microRNA coding regions in genome scale sequences. BMC Bioinformatics. 2011;12(1):107.

49. Palani SN, Elangovan S, Menon A, Kumariah M, Tennyson J. An efficient nucleic acids extraction protocol for Elettaria cardamomum. Biocatalysis Agricultural Biotechnol. 2019;17:207-12.

50. Dai X, Zhuang Z, Zhao PX. psRNATarget: a plant small RNA target analysis server (2017 release). Nucleic Acids Res. 2018:46(W1):W49-54.

\section{Publisher's Note}

Springer Nature remains neutral with regard to jurisdictional claims in published maps and institutional affiliations.
Ready to submit your research? Choose BMC and benefit from:

- fast, convenient online submission

- thorough peer review by experienced researchers in your field

- rapid publication on acceptance

- support for research data, including large and complex data types

- gold Open Access which fosters wider collaboration and increased citations

- maximum visibility for your research: over $100 \mathrm{M}$ website views per year

At $\mathrm{BMC}$, research is always in progress.

Learn more biomedcentral.com/submissions 